\title{
Model Pengembangan Pendidikan Pancasila untuk bidang Ilmu Hubungan Internasional
}

\author{
Hastangka ${ }^{1}$, Muhammad Farid ${ }^{2}$ \\ ${ }^{1}$ Universitas Mercu Buana Yogyakarta, ${ }^{2}$ President University, Cikarang, Jakarta \\ hastangka@mercubuana-yogya.ac.id, mfarid@president.ac.id
}

\begin{abstract}
Abstrak: Pendidikan Pancasila merupakan mata kuliah wajib umum yang menjadi bagian penting dalam proses pendidikan di perguruan tinggi. Sebagai mata kuliah wajib umum, pendidikan Pancasila bertujuan untuk membentuk karakter mahasiswa untuk memiliki dasar dasar nilai berbangsa dan bernegara, pengetahuan tentang sistem nilai hidup berbangsa dan bernegara, serta orientasi dan wawasan untuk menjadi bangsa Indonesia yang berjati diri Pancasila. Mata kuliah Pancasila diberikan kepada seluruh mahasiswa lintas disiplin atau bidang ilmu. Persoalan yang sering muncul, mata kuliah Pancasila terkadang belum kontekstual dan relevan dalam bidang ilmu tertentu. Tujuan dari penelitian ini adalah mengkaji dan menganalisis model pengembangan mata kuliah pendidikan Pancasila di bidang ilmu hubungan Internasional. Metode penelitian ini merupakan kajian literatur dan studi empirik model pengembangan pendidikan Pancasila pada bidang ilmu Hubungan Internasional. Hasil dari penelitian ini menunjukkan bahwa model pembelajaran pendidikan Pancasila pada bidang ilmu hubungan internasional dapat dilakukan dengan menghubungkan materi Pancasila dengan isu isu strategis internasional melalui metode interaktif, dialog dan studi kasus. Kesimpulan dari penelitian ini menunjukkan bahwa materi pendidikan Pancasila menjadi sangat relevan dan kontekstual dalam bidang ilmu hubungan internasional.
\end{abstract}

Kata Kunci : Model, pendidikan, Pancasila, Hubungan internasional.

Abstract: Pancasila education is a general compulsory subject that is an important part of the education process in higher education. As a general compulsory subject, Pancasila education aims to shape the character of students to have the basic values of the nation and state, the value system of life, as well as orientation and insight to become an Indonesian nation with Pancasila identity. Pancasila courses are given to all students across disciplines or fields of science. The problem that often arises is that the Pancasila course is sometimes not contextual and relevant in certain fields of science. The purpose of this research is to study and analyze the development model of Pancasila education courses in the field of international relations. This research method is a literature review and empirical study of the Pancasila education development model in the field of International Relations. The results of this study indicate that the Pancasila education learning model in the field of international relations can be carried out by connecting Pancasila material with international strategic issues through interactive methods, dialogue and case studies. The conclusion of this study shows that the Pancasila education material is very relevant and contextual in the field of international relations.

Keywords: Model, education, Pancasila, International relations. 


\section{Pendahuluan}

Pendidikan Pancasila merupakan salah satu mata kuliah dan bagian penting dalam pendidikan di perguruan tinggi. Dalam sejarah pendidikan di Indonesia, mata kuliah Pancasila atau dikenal Pendidikan Pancasila sudah mulai diperkenalkan sejak periode tahun 1989 melalui terbitnya Undang Undang Nomor 2 Tahun 1989 tentang Sistem Pendidikan Nasional. Istilah kurikulum wajib yang memuat mata kuliah atau mata pelajaran Pancasila sudah ada pada periode tahun 1989 untuk pendidikan formal. Sehingga, pada periode itu muncul berbagai studi dan buku tentang Pancasila yang diterbitkan oleh berbagai akademisi di perguruan tinggi. Mata kuliah Pendidikan Pancasila pada perguruan tinggi dilaksanakan untuk semua bidang studi dengan bobot 2 SKS. Adapun materi pendidikan Pancasila yang diajarkan dan diberikan pada jenjang pendidikan tinggi secara umum menyangkut antara lain:1. Sejarah Pancasila, 2. Pancasila sebagai sistem filsafat,3. Pancasila sebagai dasar Negara, 4. Pancasila sebagai pandangan hidup bangsa, 5. Pancasila sebagai sistem etika. Materi tersebut merupakan materi dasar dan standar yang telah dikembangkan oleh para akademisi dan pemerintah melalui Kementerian Pendidikan dan Kebudayaan pada waktu itu. Dalam perkembangannya, mata kuliah ini mengalami berbagai perubahan dan perkembangan mulai dari konten dan pendekatan yang dilakukan. Pada periode tahun 1998/9an, mata kuliah Pancasila sempat tidak diajarkan karena era reformasi yang melanda Indonesia. Era reformasi tersebut telah berdampak pada proses perubahan sosial dan politik di Indonesia yang berdampak pada mata kuliah pendidikan Pancasila tidak diajarkan pada jenjang perguruan tinggi. Hal tersebut diperkuat dengan terbitnya Undang Undang Nomor 20 Tahun 2003 tentang Sistem Pendidikan Nasional yang menghilangkan mata kuliah Pancasila menjadi mata kuliah wajib nasional pada perguruan tinggi. Dinamika pendidikan Pancasila baik secara internal dan eksternal terjadi sampai pada tahun 2012, dimana pendidikan Pancasila mulai kembali ada di perguruan tinggi melalui dasar Undang Undang Nomor 12 Tahun 2012 tentang Pendidikan Tinggi yang mencantumkan Pancasila menjadi salah satu mata kuliah wajib nasional. Studi yang dilakukan oleh Hastangka dan Danang Prasetyo menunjukkan bahwa hasil analisis kebijakan pendidikan Pancasila di perguruan Tinggi masih dinilai lemah dalam proses pembentukan jati diri dan kepribadian bangsa. Proses pelemahan kebijakan pendidikan ini dapat ditelusuri dari upaya inkonsistensi kebijakan pendidikan Pancasila (Hastangka dan Danang Prasetyo, 2019). Peran dan fungsi Pancasila pada era reformasi ini dianggap kurang memiliki peran dan fungsi serta bermanfaat besar secara konkret. Politik pemaknaan atas Pancasila yang beragam sejak paska reformasi ini telah menjadi faktor pendukung Pancasila dalam dunia pendidikan masih dinilai dari produk rezim orde baru (Hastangka, 2018).

Secara umum mata kuliah pendidikan Pancasila diberlakukan untuk semua bidang studi, sehingga proses pembelajaran pendidikan Pancasila berlangsung secara serentak, tersistematis, dan terstruktur. Namun, dalam praktek pembelajaran dan pengajaran Pancasila pada perguruan tinggi dengan berbagai macam disiplin ilmu dinilai masih memberikan kendala dan persoalan. Kendala yang muncul ialah masih belum ditemukan model dan format yang ideal dalam proses pengajaran dan pembelajaran pendidikan Pancasila untuk disiplin ilmu tertentu. Persoalan ini muncul karena setiap perguruan tinggi memiliki program studi dan disiplin ilmu yang beragam. Sehingga model pengajaran dan pembelajaran Pancasila seharusnya tidak sama antara bidang ilmu eksakta 
dan bidang ilmu non eksakta. Kondisi yang terjadi, proses pengajaran dan pembelajaran Pancasila sering ditemukan masih sama. Penelitian tentang model pengembangan mata kuliah Pancasila untuk bidang ilmu Hubungan Internasional menjadi penting dilakukan untuk menganalisis dan mendeskripsikan tentang bagaimana model pengembangan mata kuliah Pancasila bagi mahasiswa di program studi ilmu hubungan internasional. Program studi ilmu hubungan internasional menjadi program studi yang strategis karena berkaitan dengan hubungan internasional, interaksi dengan negara lain, dan diplomasi luar negeri. Penguatan karakter bagi generasi muda atau mahasiswa yang belajar pada program studi hubungan internasional akan menjadi penting untuk membawa misi kebangsaan dan Pancasila di kancah luar negeri semakin kuat. Upaya ini juga untuk membekali para mahasiswa membela dan memperjuangkan kepentingan bangsa dan negara di atas kepentingan internasional. Penelitian ini bertujuan untuk menguraikan dan mendeskripsikan tentang konsep dan model pengajaran dan pembelajaran pendidikan Pancasila bagi mahasiswa di program studi ilmu hubungan internasional yang kontekstual dan sesuai dengan kebutuhan program studi yang ada. Hal ini bertujuan untuk memberikan penanaman nilai nilai Pancasila agar lebih dapat dihayati dan diresapi ke seluruh eleman generasi muda. Untuk itu, mata kuliah Pancasila diharapkan bisa sinergi dan sinkron dengan program studi yang ada.

\section{Metode Penelitian}

Model dan metode penelitian ini menggunakan pendekatan metode kualitatif yang memfokuskan pada kajian atau studi literatur dan fenomenologi. Penelitian ini dilakukan selama 1 semester dengan subyek kajian pada model pengajaran dan pembelajaran mata kuliah Pancasila untuk bidang ilmu studi ilmu hubungan internasional. Penelitian ini melalui studi kasus pelaksanaan pendidikan Pancasila di perguruan tinggi khususnya pada program studi ilmu hubungan internasional. Sumber data penelitian ini diperoleh dari hasil penelitian sebelumnya, jurnal ilmiah yang membahas tentang Pancasila, dokumen Negara seperti peraturan perundang undangan, dan hasil dari kajian empirik yang ada. Metode analisis data menggunakan analisis teks dan analisis kritis. Peneliti akan menganalisis tentang model pengembangan pengajaran dan pembelajaran mata kuliah Pancasila untuk bidang ilmu Hubungan Internasional.

\section{Hasil dan Pembahasan}

\section{Kilas Balik Mata Kuliah Pancasila di Perguruan Tinggi}

Pada dasarnya hakikat pendidikan nasional adalah pendidikan yang berakar pada kebudayaan bangsa Indonesia dan yang berdasarkan pada Pancasila dan Undang Undang Dasar 1945(UU No.2/1989 tentang Sistem Pendidikan Nasional pasal 1 ayat 2). Pendidikan menjadi bagian penting dalam proses memajukan bangsa dan Negara. Dengan pendidikan, hasil hasil pembangunan dapat terwujud dengan melahirkan sumber daya manusia yang berkualitas, berkompetensi dan memiliki jati diri yang berdasarkan pada Pancasila. Filosofi pendidikan ini telah terjemahkan dalam peraturan perundang-undangan di Indonesia. Sebagaimana dalam pasal 3 UU No.2/1989 menjabarkan bahwa pendidikan nasional berfungsi untuk mengembangkan kemampuan serta meningkatkan mutu kehidupan dan martabat manusia Indonesia dalam rangka upaya mewujudkan tujuan 
nasional. Dasar yuridis Undang Undang ini menarik untuk dikaji dan diterjemahkan dalam konteks pendidikan sekarang khususnya pendidikan yang mengarah pada karakter peserta didik. Perkembangan dan perubahan peraturan perundang undangan yang terjadi tidak selalu lebih baik atau sebaliknya, namun dalam proses perjalanan sejarah peraturan perundang-undangan tentang sistem pendidikan nasional hal yang menarik dapat dicermati ialah pada bagian pengertian tentang pendidikan nasional dan tujuan pendidikan nasional. Perubahan pengertian dan tujuan pendidikan nasional memiliki dampak yang mendasar dalam mencapai luaran pendidikan nasional secara khusus pendidikan formal mulai dari jenjang pendidikan dasar sampai pada pendidikan tinggi.

Posisi Pancasila dalam ranah pendidikan memiliki peran penting sebagai mata pelajaran atau kuliah penciri nasional. Mata kuliah Pancasila secara khusus di perguruan tinggi berperan sebagai proses pembentukan jati diri dan pengembangan karakter mahasiswa dalam segala aspek kehidupan. Pancasila merupakan dasar falsafah dan pandangan hidup bangsa Indonesia. Notonagoro dan Wreksuhardjo (1987) menjelaskan bahwa Pancasila adalah dasar filsafat, asas kerohanian (ideologi) Negara Republik Indonesia. Pancasila adalah filsafat hidup bangsa Indonesia (Notonagoro dan Wreksuhardjo,1987:1). Proses ideologisasi Pancasila dipahami sebagai proses pendidikan dan pembentukan karakter masyarakat dan segenap elemen bangsa tentang arti penting kedudukan dan fungsi Pancasila di Indonesia.

Penguatan Pancasila dalam dunia pendidikan mulai diletakkan sejak pada periode tahun 1951an ketika terbitnya naskah pidato Promosi Honoris causa Prof.Mr.Notonagoro kepada P.J.M Soekarno pada 19 Desember 1951 dalam ilmu hukum di Universitas Gadjah Mada Yogyakarta. Judul pidato Prof. Mr. Notonagoro tersebut ialah "Pantjasila Dasar filsafat Negara Republik Indonesia" (Notonagoro, 1957). Sejak itu, perkembangan ilmu Pancasila di Perguruan Tinggi mulai dirintis dan digagas oleh Notonagoro. Mata kuliah pertama kali yang diberikan di Universitas Gadjah Mada bernama mata kuliah Filsafat Pancasila pada periode tahun 1955an sampai pada era tahun 1980an, kemudian berkembang setelah periode tersebut bertambah menjadi mata kuliah Pancasila sampai sekarang. Materi awal Filsafat Pancasila yang diajarkan dan dikembangkan untuk pertama kalinya membahas tentang Pancasila dari aspek kefilsafatan yang dapat dilihat pada Tabel 1:

Tabel.1 Pokok Pokok Materi Filsafat Pancasila

\begin{tabular}{cl}
\hline No & \multicolumn{1}{c}{ Pokok Pokok Materi } \\
\hline 1. & Pancasila pemersatu bangsa \\
2. & Isi Arti Pancasila sebagai dasar Filsafat Negara \\
3. & Landasan daripada Pancasila sebagai dasar filsafat Negara \\
4. & Uraian tentang Sila pertama dari sila Pancasila \\
5. & Uraian tentang Sila kedua dari sila Pancasila \\
6. & Uraian tentang Sila ketiga dari sila Pancasila \\
7. & Uraian tentang Sila Keempat dari sila Pancasila \\
8. & Uraian tentang Sila kelima dari sila Pancasila \\
\hline 9. & Pelaksanaan dari Pancasila \\
\hline Sumber: Notonagoro, 1980
\end{tabular}

Sumber: Notonagoro, 1980. 
Pokok pokok materi pada tabel 1 di atas merupakan materi dasar yang pertama kali diperkenalkan dalam mata kuliah Filsafat Pancasila oleh Notonagoro. Kemudian dalam perkembangan berikutnya, munculnya Kebijakan Pemerintah tentang Pedoman dan Penghayatan dan Pengamalan Pancasila (P4), materi materi pokok tersebut mulai berkembang dengan tema tema yang lebih sistematis. Filsafat Pancasila kemudian juga membahas tentang pengertian filsafat, fungsi dan tujuan filsafat, serta aliran aliran filsafat. Setelah itu baru membahas tentang Pancasila sebagai sistem filsafat, pokok pokok isi filsafat Pancasila, dan pengamalan dan penghayatan Pancasila (Soemasdi,1985). Penggunaan mata kuliah Pendidikan Pancasila secara nasional berkembang pada periode tahun 1989an, bersamaan dengan terbitnya Undang Undang Nomor 2 Tahun 1989 tentang Sistem Pendidikan Nasional yang di dalamnya mencantumkan isi atau muatan kurikulum pada pendidikan terdiri atas Pancasila. Sejak itu mata kuliah Pendidikan Pancasila menjadi mata kuliah wajib di perguruan tinggi dan menjadi popular dalam khasanah pengetahuan umum di perguruan tinggi.

\section{Materi Muatan mata kuliah Pancasila di Perguruan Tinggi}

Materi muatan mata kuliah Pancasila di perguruan tinggi dalam 1 dekade terakhir ini mengalami perkembangannya. Sejak terbitnya Undang Undang Nomor 12 Tahun 2012 tentang Pendidikan Tinggi yang mewajibkan Pancasila sebagai mata kuliah wajib pada pendidikan tinggi. Selain itu, terbitnya buku ajar mata kuliah wajib umum Pendidikan Pancasila pada tahun 2016 dari Direktorat Jenderal Pembelajaran dan Kemahasiswaan Kementerian Riset, Teknologi, dan Pendidikan Tinggi. Dalam buku ajar yang digunakan secara nasional ini terdiri atas 7 bab yang dimuat pada Tabel 2:

Tabel 2. Muatan Materi Pancasila di Perguruan Tinggi

\begin{tabular}{ll}
\hline Bab & \multicolumn{1}{c}{ Muatan Materi } \\
\hline I & Pengantar Pendidikan Pancasila \\
II & Bagaimana Pancasila dalam Arus Sejarah Bangsa Indonesia \\
III & Bagaimana Pancasila menjadi Dasar Negara Republik Indonesia \\
IV & Mengapa Pancasila menjadi Ideologi Negara? \\
V & Mengapa Pancasila merupakan sistem Filsafat? \\
VI & Bagaimana Pancasila menjadi sistem Etika? \\
VII & Mengapa Pancasila menjadi dasar pengembangan Ilmu? \\
\hline
\end{tabular}

Sumber: Dirjen Dikti,2016.

Muatan materi Pancasila di Perguruan tinggi pada tabel.2 di atas menjadi dasar acuan secara umum bagi penyelenggaraan pengajaran dan pembelajaran Pancasila di Perguruan Tinggi di Indonesia. Bahan buku ajar ini dapat diakses secara gratis pada website dikti.go.id. Muatan materi Pancasila lainnya juga dapat diakses melalui berbagai buku yang telah diterbitkan oleh akademisi. Materi ini di perguruan tinggi digunakan sebagai acuan untuk memberikan pembelajaran Pancasila pada semua jenjang baik program diploma maupun Sarjana (Strata 1) pada seluruh program studi. 


\section{Model Pengembangan Mata kuliah Pancasila pada Ilmu Hubungan Internasional}

Program Studi Ilmu Hubungan Internasional merupakan program studi yang strategis. Keberadaan program studi ini menjadi bagian dari kepentingan nasional untuk menjadikan para lulusan dan akademisi memiliki jiwa nasionalis, kebangsaan, dan memperjuangkan kepentingan nasional di atas kepentingan internasional. Kehidupan berbangsa dan bernegara, tidak lepas dari pengaruh geopolitik dan geostrategis internasional. Program program internasional sering membawa dampak dalam proses pembentukan jati diri dan keberlangsungan bangsa dan negara. Agenda global yang dibawa melalui konsep, materi, isu isu internasional dapat memberikan pengaruh bagi generasi bangsa melalui program studi hubungan internasional untuk kehilangan rasa nasionalismenya. Untuk itu, penguatan karakter dan jati diri generasi muda yang belajar pada program studi hubungan internasional tetap dapat berpijak pada jati diri bangsanya dan berpegang teguh pada Pancasila sebagai dasar dan pandangan hidup bangsa. Model pengembangan mata kuliah Pancasila menjadi penting untuk dikembangkan karena model pembelajaran diartikan sebagai cara penyajian bahan ajar yang digunakan oleh dosen untuk menyampaikan materi yang ada. Studi yang dilakukan Winata dan Hasanah menunjukkan bahwa model pembelajaran menjadi bagian penting dari aspek metode pembelajaran. Model yang ditawarkan untuk pembentukan karakter peserta didik dapat dilakukan melalui interaksi sosial (Winata dan Hasanah, 2021). Studi ini lebih menekankan pada model dan metode pembelajaran. Dalam studi model pengembangan mata kuliah belum banyak diulas secara mendalam. Studi yang lain lebih banyak membahas model dan implementasi materi ajar atau bahan ajar.

Materi mata kuliah Pancasila secara umum sudah terstandar secara nasional. Muatan materi pendidikan Pancasila diterbitkan dalam bentuk buku ajar oleh Direktorat Jenderal Pembelajaran dan Kemahasiswaan, Kementerian Riset, Teknologi dan Pendidikan Tinggi Republik Indonesia tahun 2016. Secara materi, Pancasila digunakan sebagai pembelajaran wajib umum pada setiap perguruan tinggi dengan bobot 2 SKS untuk semua program studi di lingkungan perguruan tinggi, termasuk program sudi ilmu hubungan internasional. Program studi ilmu hubungan internasional memiliki kurikulum inti yang memfokuskan pada isu isu internasional. Program Studi ilmu hubungan internasional memiliki capaian pembelajaran yang telah ditentukan oleh Asosiasi Ilmu Hubungan Internasional Indonesia (AIHII). Asosiasi ini merumuskan 4 capaian pembelajaran yang diukur dari aspek sikap, penguasaan pengetahuan, Keterampilan khusus, dan Keterampilan umum. Salah satu aspek sikap yang dituangkan dalam capaian pembelajaran ini adalah berkontribusi dalam peningkatan mutu kehidupan bermasyarakat, berbangsa, dan bernegara dan kemajuan beradaban berdasarkan Pancasila (http://www.aihii.or.id/wp-content/uploads/2018/04/CP_KKNI-_S1_HI.pdf).

Aspek sikap yang telah dirumuskan oleh AIHII ini menjadi bagian penting untuk membentuk jati diri dan kepribadian para akademisi program studi ilmu hubungan internasional. Ilmu Hubungan Internasional merupakan mata kuliah yang strategis dalam upaya untuk mempersiapkan generasi muda dan mahasiswa menjadi seorang diplomat yang berkarakter dan berjati ke Indonesiaan, professional, dan kompeten di bidangnya. Isu isu strategis nasional yang dihadapi Indonesia baik secara geopolitik maupun strategis salah satunya juga dipengaruhi oleh persoalan internasional. Peran ilmu hubungan internasional untuk menjadikan bangsa Indonesia sebagai bangsa yang bermartabat dan 
berjati diri diperlukan landasan yang kokoh dan nilai nilai keindonesiaan yang mapan sebagaimana terdapat di dalam Pancasila.

Peran penting mata kuliah Pancasila dalam bidang ilmu hubungan internasional menjadi sangat relevan dan kontekstual. Untuk itu, perlu adanya rumusan model pengembangan mata kuliah pendidikan Pancasila pada ilmu hubungan internasional. Selama ini, pelaksanaan pendidikan Pancasila pada perguruan tinggi atau program studi yang bersifat lintas disiplin ilmu atau bidang sosial humaniora masih sebatas pada penyampaian materi materi pokok tentang Pancasila mulai dari sejarah Pancasila, sila sila Pancasila, aktualisasi Pancasila, dan Pancasila sebagai dasar paradigma pengembangan ilmu. Dalam ilmu hubungan internasional rumusan model pengembanngan mata kuliah pendidikan Pancasila belum terlalu banyak dikembangkan untuk dikaitkan dengan seputar isu isu strategis internasional dan nasional dalam kerangka membangun diplomasi internasional dan melahirkan para calon pemimpin bangsa, akademisi, dan diplomat di bidang hubungan internasional. Berikut ini model pengembangan mata kuliah pendidikan Pancasila yang dapat diterapkan dalam bidang ilmu hubungan internasional sebagaimana tergambar dalam bagan 1 .

Bagan 1 Model Pembelajaran Pancasila pada Ilmu Hubungan Internasional

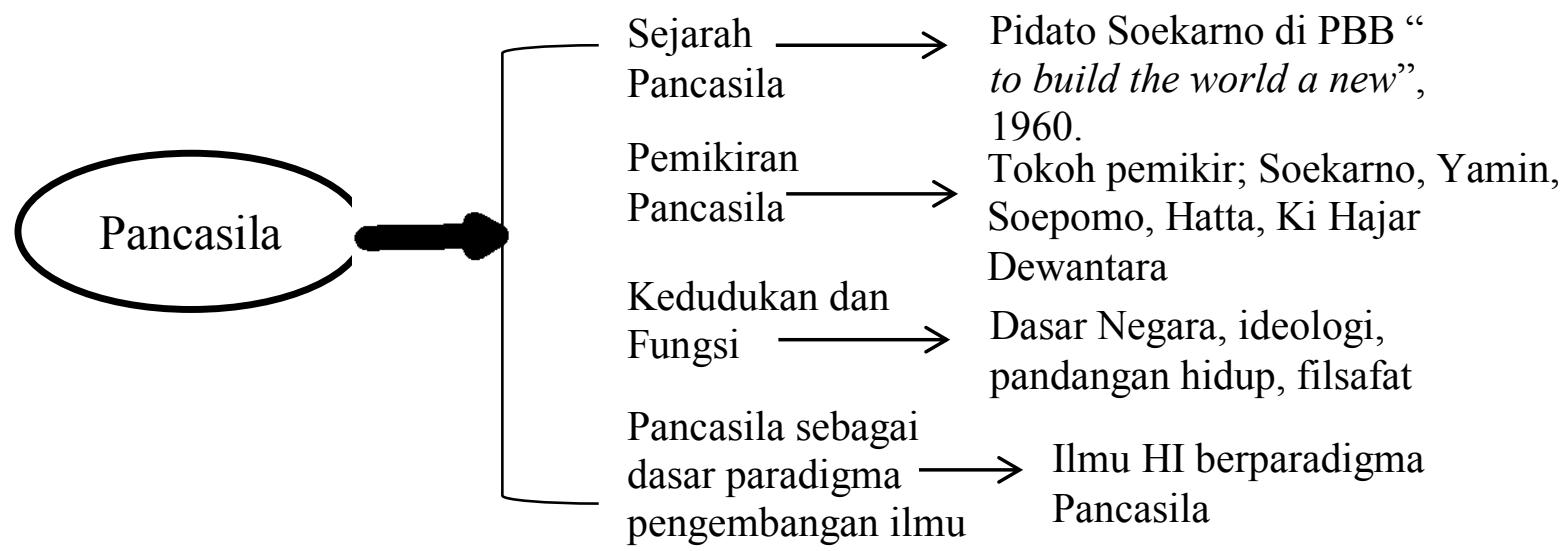

Sumber: hasil analisis penulis,2020.

Berdasarkan dari bagan 1 di atas menunjukkan bahwa model pengembangan mata kuliah pendidikan Pancasila pada bidang ilmu hubungan internasional dapat di kontekstualisasi dengan mata kuliah inti seperti materi diplomasi internasional. Pancasila juga pernah ditawarkan oleh Soekarno ketika menyampaikan pidato di PBB dengan judul "to build the world a new", Membangun tatanan dunia baru. Pidato Soekarno ini menjadi bagian penting dalam diplomasi Indonesia di dunia untuk membangun tatanan peradaban dunia baru untuk tidak memihak antara blok barat dan blok timur. Catatan penting dalam materi sejarah Pancasila berbagai gagasan Soekarno tentang Pancasila diadopsi oleh Negara tentang seperti Malaysia dengan rukun nagara. Konsep rukun nagara yang dirumuskan pada tahun 1970an, termasuk konsep lebih muda dari Pancasila yang dirumuskan pada tahun 1945. Begitu juga mata kuliah tentang tokoh pemikir tentang Pancasila yang pada awal 
periode menawarkan konsep tentang Negara dan bangsa. Konsepsi Negara dalam konteks Pancasila dapat menjadi bagian dari studi perbandingan di kalangan ilmu hubungan internasional yang membahas tentang konsep Negara dari berbagai tokoh pemikir asing atau luar. Memahami cara pandang Negara, masyarakat, dan kelembagaan Negara berdasarkan Pancasila dan berdasarkan perspektif hubungan internasional akan memberikan wawasan baru bagi mahasiswa hubungan internasional dalam melihat perbandingan Negara Negara. Materi tentang kedudukan dan fungsi Pancasila dapat menjadi bagian diskursus bagi para mahasiswa hubungan internasional ketika mempelajari topik perbandingan ideologi, pandangan hidup bangsa, dan filsafat kenegaraan atau filsafat politik. Teori kekuasaan versi dari pemikir barat dengan versi Pancasila menjadi menarik untuk proses pembelajaran di kelas kelas Pancasila di bidang ilmu hubungan internasional. Materi berikutnya, Pancasila sebagai dasar paradigma pengembangan ilmu dapat digunakan untuk mengembangkan ilmu HI yang berparadigma Pancasila. Konsep materi di atas dapat dilaksanakan melalui model pembelajaran yang interaktif, diaologis, dan melalui studi kasus. Berdasarkan hasil penelitian ini menunjukkan bahwa upaya untuk mengembangkan mata kuliah pendidikan Pancasila untuk bidang ilmu hubungan internasional menjadi sangat penting dan menarik dilakukan. Pancasila menjadi mata kuliah yang kontekstual dan sesuai dengan kebutuhan mahasiswa dan bidang ilmu yang dituju.

\section{Kesimpulan dan Saran}

Pancasila merupakan salah satu mata kuliah wajib umum yang diselenggarakan di perguruan tinggi di Indonesia memiliki peran penting dalam membentuk dan membangun karakter peserta didik secara khusus mahasiswa untuk memiliki jiwa dan karakter kebangsaan yang kuat. Mata kuliah Pancasila ini memiliki karakter dapat diajarkan kepada seluruh disiplin ilmu dan program studi di perguruan tinggi. Sebagai mata kuliah umum, Pancasila memiliki peran dan ruang yang sangat terbuka untuk dikontekstualisasikan ke dalam disiplin ilmu ilmu khusus seperti hubungan internasional. Ilmu hubungan internasional memiliki peran penting dalam membangun kedaulatan dan martabat bangsa di mata internasional untuk itu kolaborasi dan sinergi antara pengetahuan tentang Indonesia dan luar negeri menjadi penting untuk meletakkan peran penting ilmu hubungan internasional menjadi proses dalam pembentukan jati diri generasi muda atau calon diplomat.

Mata kuliah Pancasila dapat dikembangkan dan diterapkan pada bidang ilmu hubungan internasional. Model pembelajaran mata kuliah pendidikan Pancasila pada bidang ilmu hubungan internasional dapat diwujudkan dalam bentuk pemilihan materi yang sesuai dengan Pancasila dan penyusunan model pembelajaran dengan metode yang tepat seperti metode interaktif, dialog, dan studi kasus menjadi bagian penting dalam pendidikan Pancasila yang kreatif dan inovatif. 


\section{Daftar Pustaka}

Dirjen Dikti.(2016). Buku Ajar Mata Kuliah Wajib Umum Pendidikan Pancasila. Jakarta:

Dirjen Pembelajaran dan Kemahasiswaan, Kemenristek Dikti.

Hastangka.(2018). Politik Pemaknaan Atas Pancasila Pada Era Pascareformasi. Jurnal

Waskita, Vol.2 No.2, (2018). Hal.1-12.

Hastangka dan Danang Prasetyo.(2019). Analisis Pelaksanaan Mata Kuliah Pendidikan

Pancasila di Perguruan Tinggi, Jurnal Rontal Keilmuan PKn Vol.5/No.2/November 2019, hal. 1-12.

Notonagoro.(1957). Pantjasila Dasar Filsafat Negara Republik Indonesia, Pidato Promosi

Honoris Causa dalam ilmu hukum pada 19 Desember 1951, Yogyakarta: Universitas Gadjah Mada.

Notonagoro.(1980). Pancasila secara ilmiah Populer.cetakan kelima. Jakarta: Pantjuran Tudjuh.

Notonagoro dan Wreksosuhardjo S.(1987). Pancasila Yuridis Kenegaraan.

Yogyakarta:Hanindita.

Soemasdi.H.(1985). Pemikiran tentang Filsafat Pancasila. Yogyakarta: Andi Offset.

Undang Undang Nomor 12 Tahun 2012 tentang Pendidikan Tinggi.

Undang-Undang Republik Indonesia Nomor 2 Tahun 1989 Tentang Sistem Pendidikan

Nasional.

Undang Undang Nomor 20 Tahun 2003 tentang Sistem Pendidikan Nasional.

Winata Koko Adya. Hasanah,Aan.(2021). mplementasiModel Pembelajaran Interaksi

Sosial Untuk Meningkatkan Karakter Peserta Didik. Jurnal Pendidikan, Vol.9, No.1, Januari 2021,hal.22-32.

Internet:

http://www.aihii.or.id/wp-content/uploads/2018/04/CP_KKNI-_S1_HI.pdf. 